\title{
Correction to: The mouse and ferret models for studying the novel avian-origin human influenza A (H7N9) virus
}

Lili Xu', Linlin Bao ${ }^{\dagger}$, Wei Deng ${ }^{\dagger}$, Hua Zhu, Ting Chen, Qi Lv, Fengdi Li, Jing Yuan, Zhiguang Xiang, Kai Gao, Yanfeng Xu, Lan Huang, Yanhong Li, Jiangning Liu, Yanfeng Yao, Pin Yu, Weidong Yong, Qiang Wei, Lianfeng Zhang and Chuan Qin*

\section{Correction to: Virol J 10, 253 (2013)}

https://doi.org/10.1186/1743-422X-10-253

Following publication of the original article [1], the authors identified an error in Fig. 4. The immunohistochemical result of intestine of inoculated mouse was unfortunately misplaced, although the error would not change the interpretation and conclusions of this work. The wrong photo has been corrected in the new figure. Scale bars of each image were also complemented.

The correct figure is given below.

Published online: 24 June 2020

\section{Reference}

1. Xu, et al. The mouse and ferret models for studying the novel avian-origin human influenza A (H7N9) virus. Virol J. 2013;10:253 http://www.virologyj. com/content/10/1/253.

The original article can be found online at https://doi.org/10.1186/1743422X-10-253.

* Correspondence: qinchuan@pumc.edu.cn

${ }^{+}$Lili Xu, Linlin Bao and Wei Deng contributed equally to this work. Institute of Laboratory Animal Sciences, Chinese Academy of Medical, Sciences (CAMS) \& Comparative Medicine Center, Peking Union Medical, Collage (PUMC), Key Laboratory of Human Disease Comparative Medicine, Ministry of Health, Beijing, China

(c) The Author(s). 2020 Open Access This article is licensed under a Creative Commons Attribution 4.0 International License, which permits use, sharing, adaptation, distribution and reproduction in any medium or format, as long as you give appropriate credit to the original author(s) and the source, provide a link to the Creative Commons licence, and indicate if changes were made. The images or other third party material in this article are included in the article's Creative Commons licence, unless indicated otherwise in a credit line to the material. If material is not included in the article's Creative Commons licence and your intended use is not permitted by statutory regulation or exceeds the permitted use, you will need to obtain permission directly from the copyright holder. To view a copy of this licence, visit http://creativecommons.org/licenses/by/4.0/ The Creative Commons Public Domain Dedication waiver (http://creativecommons.org/publicdomain/zero/1.0/) applies to the data made available in this article, unless otherwise stated in a credit line to the data. 
A

HC
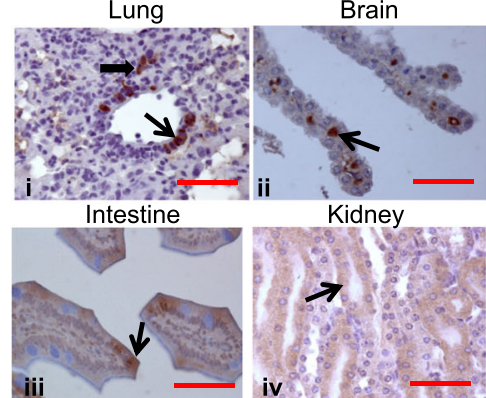

Kidney

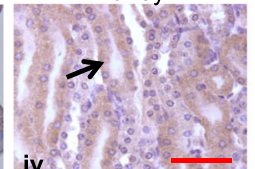

Lung 1 d.p.i.

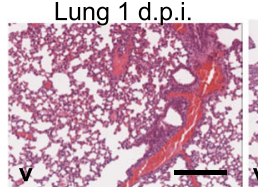

Lung 3 d.p.i.

HE

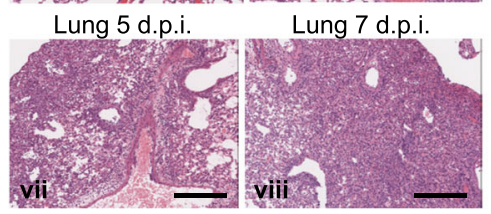

B

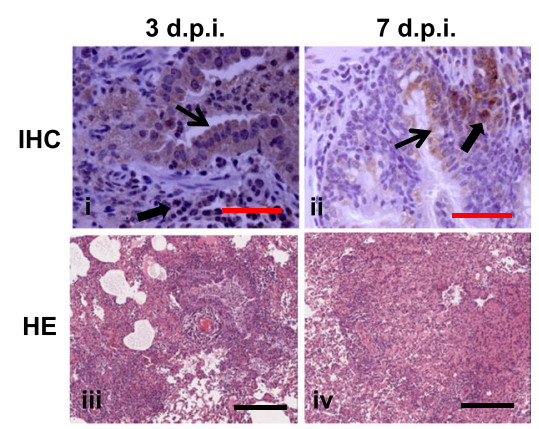

Fig. 4 Histopathological analyses of tissues of inoculated mice and ferrets. (A) Hematoxylin and Eosin (H-E) stain and immunohistochemical (IHC) analyses of tissues of inoculated mice. (B) H-E stain and IHC analyses of lungs of inoculated ferrets. Red scale bar for $\mathrm{IHC}=50 \mu \mathrm{m}$. Black scale bar for $\mathrm{H}-\mathrm{E}=200 \mu \mathrm{m}$ 